\title{
A singularidade da experiência islâmica: contexto histórico, revelação e concepção de Deus
}

\author{
The uniqueness of the Islamic experience: historical context, \\ revelation and conception of God
}

Carlos Frederico Barboza de Souza*

\begin{abstract}
Resumo
Este artigo procura apresentar aspectos importantes da espiritualidade islâmica. Parte-se de uma apresentação do contexto histórico em que surge o Islã para poder situar as raízes que vão dar uma configuração específica a esta experiência religiosa. Neste aspecto, a vida e a figura do Profeta Muhammad são fundamentais, bem como o contexto histórico da península Arábica, suas perspectivas sócio-políticas e religiosas. Em seguida, começa-se a tratar sobre a concepção de revelação singular que o Islã possui a partir da experiência com o anjo Gabriel em que um conteúdo é transmitido e deve ser repetido sem alteração pelos seguidores desta revelação. Neste aspecto, a perspectiva acerca da revelação no Islã distingue-se da concepção judaico-cristã, na qual e revelação possui uma perspectiva histórica. Por fim, tratar-se-á neste artigo sobre a concepção islâmica acerca de Deus, sobretudo no que esta concepção possui de aceno para o ponto central na espiritualidade muçulmana: a Onipotência divina e a busca da Unidade.
\end{abstract}

Palavras-chave: Islã; espiritualidade; revelação; concepção de Deus.

\begin{abstract}
This article aims to present important aspects of Islamic spirituality. To this end, it starts with a presentation of the historical context in which Islam appears in order to place the roots that will give a specific configuration to this religious experience. In that aspect, the life and the figure of the Prophet Muhammad are fundamental as well as the historical context of the Arabian Peninsula and its sociopolitical and religious perspectives. Then, one begins to handle on the conception of singular revelation that Islam has from the experience with the angel Gabriel in which content is transmitted and should be repeated without alteration by the followers of this revelation. In this aspect, the prospect about the revelation in Islam differs from the Judeo-Christian conception, in which the revelation has a historical perspective. Finally, this article will deal with the Islamic conception of God, especially as such conception nods to the central point in the Muslim spirituality: the divine omnipotence and the search for unity.
\end{abstract}

Keywords: Islam; spirituality; revelation; conception of God.

\footnotetext{
Artigo recebido em 12 de maio de 2015 e aprovado em 30 de junho de 2015.

* Doutor em Ciência da Religião pela Universidade Federal de Juiz de Fora. Professor Adjunto III da Pontifícia Universidade Católica de Minas Gerais. País de Origem: Brasil. E-mail: fred@pucminas.br
}

Horizonte, Belo Horizonte, v. 13, n. 38, p.803-828, abr./jun 2015 - ISSN 2175-5841 


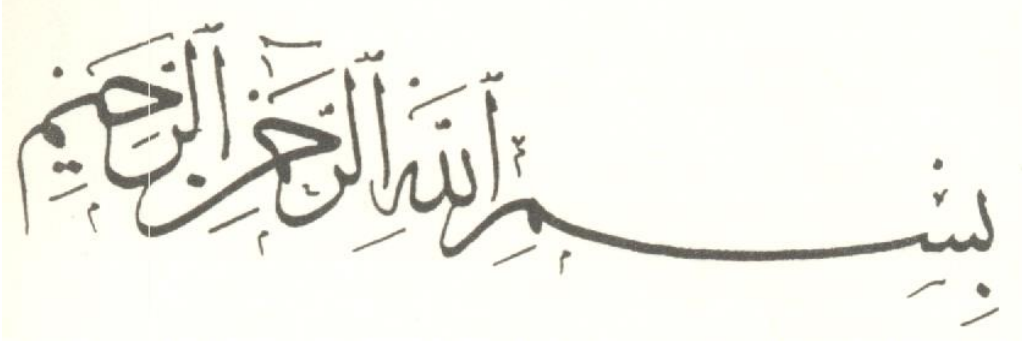

"Em nome de Deus, o Clemente, o Misericordioso"

(bismi’ Llāh al-Rahmān al-Rahīm)

\section{Introdução}

O presente artigo busca apresentar os fundamentos da experiência islâmica que estão na vida de muitos muçulmanos. Fala-se muito sobre o Islã atualmente, porém, se conhece pouco de sua experiência espiritual, de sua busca do Sagrado e de como ele é compreendido e em que contexto nasceu.

A base dessa exposição remonta à história de como se realizou esta experiência e de como ela dialoga com seu ambiente sociocultural e com as religiosidades presentes naquele momento. A partir de toda ambientação levantada por Albert Hourani, buscar-se-á entender as questões sociais prementes, vividas na época do surgimento da religião islâmica na península Arábica, assim como entender a posição da tribo dos Coraišitas nessa realidade, e em Meca nesse período. A situação era de crise, tanto do ponto de vista das relações intertribais como das relações econômicas e comerciais, o que gerava uma crise também do ponto de vista da espiritualidade dos povos ali presentes, ansiosos por caminhos que propiciassem uma integração maior entre todos.

Em seguida, após este introito histórico, o artigo centrar-se-á na discussão acerca da concepção de revelação, como entendida pela perspectiva islâmica, assim como focalizará a concepção de Deus desenvolvida nesse período. Louis Massignon (1990a, 199ob), Roger Arnaldez (1988), Robert Caspar (1983a, 1983b, 1985, 1991) e Fritjof Schuon $(1989,1990)$ serão autores que nos acompanharão nesta parte do artigo, indicando suas concepções que buscam pela profundidade e singularidade 
da experiência islâmica, sem desmerecer outras expressões religiosas, mas apontando para o que ela possui de inovador e diferente em relação às demais tradições.

Gosto de pensar as tradições religiosas como caminhos, vias, que objetivam conduzir as pessoas que optam por trilhar suas sendas - ou se sentem convidadas a empenhar suas vidas em sua direção - a atingir o que determinada tradição coloca como o clímax de sua proposta. No caso do Islã, o auge da vivência religiosa dirige-se a que o fiel que adere às suas proposições desenvolva uma vida individual e socialmente - em total acolhida e submissão a Deus. Esta proposta que se encontra presente no Islam (palavra cujo radical trilítero é: $\mathrm{S}-\mathrm{L}-\mathrm{M}$ ), quando vivenciada, propiciará a paz (SaLaM), tanto em nível social quanto individual.

O caminho a ser percorrido para atingir tal ápice envolve uma série de práticas religiosas, posturas éticas e concepções acerca do Sagrado e sua manifestação em meio à realidade humana. A maneira com que este conjunto de elementos é praticado e compreendido em determinada religião é que confere singularidade a determinada tradição religiosa. Não é diferente com o Islã.

\section{A constituição da experiência religiosa islâmica: um pouco de história}

Para se entender a experiência religiosa islâmica, se faz necessário revisitar um pouco de sua história e dos pilares que constituem esta grande tradição religiosa. Ao fazer este percurso, nos encontraremos com a fonte de onde ele brota, enraíza-se e haure sua identidade e espiritualidade. Devemos nos acercar ao Islã, ${ }^{1}$ este grande movimento religioso que surge em torno do Profeta Muḥammad ao

\footnotetext{
${ }^{1}$ Nesta abordagem, embora não se perceba o Islã como um bloco homogêneo, procurar-se-á apresentar as principais fontes e características da experiência religiosa islâmica sem, contudo, haver a preocupação de se abordar as especificidades de cada corrente ou escola. Portanto, as distinções entre sunismo e šiismo, bem como as distinções entre as escolas jurídicas dos Hanafitas, Malikitas, Shafi'itas e Hanbalitas não serão abordadas. Para melhor detalhamento da diversidade interna ao Islã. (HIRJ, 2010).
} 
redor do século VII do calendário cristão e tentar identificar os elementos principais que caracterizam este tipo de experiência religiosa.

O caminho se inicia com a experiência do profeta Muḥammad, pois será ela que dará origem a todo este movimento religioso, na medida em que a partir dela pessoas se aproximam do Profeta e começam a se inteirar acerca do que ele fala e se propõem a segui-lo.

Todos os anos, no mês de Ramadã, Muḥammad Ibn Abdallah levava sua família ao Monte Hira, nos arredores da cidade de Meca, para fazer um retiro espiritual. Além de longos momentos de oração junto ao Sumo Deus dos árabes, lá ele se dedicava também a distribuir comida e esmolas aos pobres que por ali passavam (ARMSTRONG, 1998, p. 140; ARMSTRONG, 2002, p. 55-56).

Nestes longos momentos de oração, certamente o seu contexto vital emergia. Era a situação de sua cidade, Meca, de sua tribo, os coraišitas, dos povos árabes e suas várias tribos e suas relações com os impérios que se localizavam ao seu redor.

A Península Arábica era composta, em sua maior parte, por desertos e estepes, havendo em seu interior oásis isolados, que forneciam água suficiente para o cultivo da terra. Ela era habitada por povos árabes, que falavam dialetos diferentes e levavam estilos de vida diversos. Havia os nômades criadores de camelos, carneiros ou cabras, que eram chamados de beduínos; havia também agricultores, que habitavam próximo aos oásis e havia os artesãos e comerciantes, que habitavam pequenos vilarejos e se dedicavam à organização de feiras comerciais. O equilíbrio entre estes diversos grupos era precário e o poder normalmente se concentrava nas mãos dos beduínos e dos comerciantes que viviam nos oásis, em detrimento dos artesãos e lavradores. Estes grupos se organizavam ao redor de líderes tribais, uma vez que não havia um poder centralizado, e a autoridade era exercida a partir do oásis em uma estreita relação com os mercadores que organizavam o comércio em sua área de influência (HOURANI, 1994, p. 26). 
A tribo dos coraišitas, na época de Muḥammad, era um grupo dominante. Nos anos anteriores, ela era composta por nômades das estepes da Arábia, levando uma vida dura nas incertezas do deserto. Porém, no final do século VI da era cristã, eles obtiveram um excelente êxito no comércio, o que alterou profundamente o seu perfil. Estabeleceram-se em Meca, dando-lhe um grande desenvolvimento e projeção, transformando-a em um centro de comércio internacional e alta finança. Entretanto, ao mesmo tempo em que se encontravam possuidores de riquezas, as práticas comerciais por eles desenvolvidas criaram uma sociedade extremamente excludente, capaz de levar a desintegração da tribo. Os valores tribais de ajuda mútua, principalmente de apoio aos mais fracos, encontravam-se esquecidos. A própria tribo era colocada em segundo plano, diante do desejo de acúmulo financeiro. A competição interna surge e alguns clãs, dentre eles o clã dos Hašim, de Muḥammad, sentem-se ameaçados de extinção.

No resto da Arábia, a situação não era diferente. As tribos viviam em contínuas disputas intestinas. Mesmo a tradição da chamada muruwah (ARMSTRONG, 1998, p. 141s) já não estava mais cumprindo sua função. Esta tradição surgiu para manter a sobrevivência dos povos árabes através da manutenção de um espírito comunal. Muitas vezes a muruwah é considerada sinônimo de virilidade, mas o seu sentido é mais amplo. Relaciona-se com a coragem no combate, com a capacidade de ser paciente e resignado no sofrimento; implica uma dedicação à tribo e a suas lideranças, bem como uma ética coletiva de proteção mútua. Caracteriza-se pelo igualitarismo, por uma indiferença em relação aos bens materiais, pelo cultivo da generosidade e a busca da não preocupação com o dia de amanhã.

A crise deste ethos característico dos povos árabes foi motivada por dois fatores: a excessiva acumulação financeira das tribos que se dedicavam ao comércio, como afirmado acima, e a influência de ideias dos povos vizinhos. Cercada pelo Império da Pérsia Sassânida e pelo Império Bizantino, que vinham de 
um longo período de guerras, ${ }^{2}$ a Península Arábica não lhes foi indiferente. Estes impérios atraíram muitos colonos para suas regiões mais férteis, o que fez com que seus habitantes tivessem contato com uma organização político-militar diferente, além de se defrontarem com as crenças destes povos. Por outro lado, o comércio, afora ser uma fonte de riqueza, propiciava uma mobilidade social, migrações e trocas culturais.

Nesta sociedade em transformação, a inquietação espiritual era grande: expressões religiosas plurais, conflitos ideológicos, culturais e comerciais aflorados, ideias provenientes dos grandes impérios da época, circulando e entrando em choque com as tradições tribais dos povos árabes. Tudo isso afetava o espaço do Sagrado.

Neste período anterior ao surgimento do Islã, a religião parecia não ter uma forma bem definida. Pastores e agricultores cultuavam deuses locais identificados com os astros do céu que se incorporavam nas pedras, árvores ou outros elementos da natureza. Havia também os que acreditavam que o mundo era habitado por espíritos bons e maus em formas animalescas. Era comum a presença de adivinhos, kahim, que recitavam oráculos inspirados em contatos com seres sobrenaturais. Santuários, ou haram, também se faziam presentes. Estes eram lugares sagrados e seus deuses separados dos conflitos tribais, por isto, em seu interior, era vedado qualquer tipo de violência. Com o acúmulo de riquezas decorrente da atividade comercial, estes santuários transformaram-se em centros que aliavam as peregrinações, os sacrifícios religiosos e as feiras comerciais. Meca encontrava-se nesta situação. Afora seu grande prestígio comercial, nela se encontrava a Ka’bah, santuário que atraía muitos peregrinos. Junto a ele, a autoridade era reservada aos coraišitas, que acumulavam o poder econômico e religioso na cidade.

Marcado por este contexto é que, segundo a tradição islâmica, na vigésima sétima noite do mês de Ramadã do ano 610, Muḥammad tem uma experiência que

\footnotetext{
${ }^{2}$ Estas guerras se estenderam, com intervalos, de 540 a 629. Cf. HOURANI, 1994, p. 27.
} 
propiciará o nascimento do Islã. É a “Noite do Poder ou do Destino". Ele se encontrava dormindo em uma caverna no Monte Hira, quando é acordado por um anjo que lhe ordena “Recita”. Muḥammad, como os profetas do judaísmo, resiste à ordem do anjo. Este o abraça fortemente até que ele se sentisse quase sem ar e o solta, ordenando-lhe novamente que recitasse. Diante da resistência de Muḥammad, o anjo o abraça novamente e ainda um terceiro abraço se segue. Quando ele parecia chegar aos limites de sua força, vê brotar de seus lábios o que seria a primeira revelação em língua árabe. O que o anjo lhe havia ordenado recitar se encontra no Corão,3 na sura 96:1-5: "Recita em nome do teu Senhor que criou; criou o homem de um coágulo! Recita que teu Senhor é Generosíssimo, que ensinou através do cálamo, ensinou ao homem o que este não sabia!" Nesta experiência inicia-se o que será chamado mais tarde de Qur'am (Corão), ou seja, recitação.

Porém, o Corão só vem a receber seu formato atual após certo tempo. Inicialmente, Muḥammad o recebeu e o transmitiu oralmente. Entretanto, ainda em vida do Profeta, alguns manuscritos já aparecem e os muçulmanos atribuem ao próprio Muḥammad o acompanhamento deste processo redacional. Havia, no entanto, o incentivo para a memorização do texto sagrado bem como para a recitação do mesmo, de modo que a escrita ficava em segundo plano.

No período do primeiro Califa, Abu Bakr (632-634), após a batalha de Yamama, na qual muitos companheiros do Profeta que haviam memorizado todo o Corão morreram, Umar (que seria o segundo Califa - 634-644 do calendário cristão) sugeriu que se pusesse por escrito com a finalidade de se preservar o texto corânico. Embora $\mathrm{Abu}$ Bakr tenha hesitado em fazer isto - pois o próprio Muḥammad não o fizera - encarregou Zaid Ibn Tabit, que foi o primeiro a servir o Profeta como escriba, a recolher manuscritos do Corão e prepará-los para torná-lo um Livro.

\footnotetext{
${ }^{3}$ Nas referências ao Alcorão será utilizada apenas a palavra Corão. A versão citada é ALCORÃO SAGRADO, 1980, tradução de Samil el Hayek.
}

Horizonte, Belo Horizonte, v. 13, n. 38,p.803-828, abr.jun. 2015 - ISSN 2175-5841 
Entretanto, é somente durante o califado de Uțman (644-656 do calendário cristão - terceiro califa), havendo já o Islã se expandido para territórios não árabes e havendo uma confusão entre os muçulmanos devido a outros dialetos em que o Corão havia sido revelado (segundo tradição islâmica, o Corão fora revelado em sete dialetos árabes distintos), reuniu-se um conselho que optou por unificar a comunidade a partir de um texto único no dialeto Coraišita, o mesmo de Muḥammad. É a versão "Uțmani” que é a utilizada até hoje.

A experiência religiosa islâmica, portanto, marcada pela revelação corânica, surge neste contexto complexo, tanto em termos sociais quanto religiosos. E surge como uma resposta divina a este momento de crise e conflitos, sinalizando uma de suas características primordiais: que o Deus, no qual creem os muçulmanos, se manifesta à humanidade por meio de pessoas privilegiadas, que são seus profetas e mensageiros. É este mesmo Deus que escolhe, por iniciativa de seu amor gratuito e não por alguma necessidade própria, na liberdade, se comunicar aos seres humanos. Trata-se de uma revelação que não se quer nova, mas apenas intenciona restaurar o monoteísmo primitivo de Abraão e professado pela tradição bíblica, mas que fora desvirtuado pelos judeus e depois pelos cristãos.

Na vida do muçulmano a consequência da revelação corânica é a adesão à vontade de Deus, manifestada principalmente no Corão. Não é apenas uma crença em verdades, mas uma atitude que movimenta todo o ser do crente em seu empenho de responder ao apelo divino.

Neste sentido, o termo Islã possui relação profunda com a perspectiva corânica acerca da revelação, pois derivado da raiz árabe S-L-M, significa, primariamente, paz. Desta raiz primária, decorre um sentido secundário que quer dizer submissão. Assim, "sua conotação total é a paz que vem quando a vida individual se submete a Deus" (SCHWARTZ, 2001, p. 13), acolhendo e abraçando seus ordenamentos em práticas concretas, na sua subjetividade e na vida social.

O significado da palavra Islã também pode ser decorrente da forma verbal Aslama, que quer dizer “dar-se totalmente a Deus com espírito de gratidão", 
conforme afirma o verso corânico: "Consagro-me a Deus assim como aqueles que me seguem" (Corão 3: 20).4 Diante desta revelação, o muçulmano é um muwahhid, aquele que afirma a unidade de Deus e que busca revelá-la, promovendo a integração do mundo da multiplicidade à luz da Unidade.

Além do Corão, Allāh (الله), se utilizou de outras formas de comunicação. São elas o Profeta, através da sua sunna (tradição) e de seus Hadițs,5 e a Comunidade, ummah. Através de todas estas mediações e manifestações divinas para o muçulmano, constituem-se e elaboram-se sua concepção de Deus e de ser humano, assim como suas principais crenças.

\section{Corão}

O Corão, milagre supremo do Islã, é o livro da grande teofania que é a revelação mesma de Allāh, a Palavra "enlivrada”, tendo o mesmo significado para os muçulmanos que a encarnação de Jesus Cristo tem para os cristãos. Ele é a Palavra eterna e incriada proposta no "tempo" dos seres humanos por inspiração direta de Deus. É o "Verbo Enlivrado", “que se fez escrita”. Escrita que se materializou na caligrafia. Caligrafia que representa corpo visível da divina palavra” (HANANIA, 1999, p. 14), objeto de veneração e meditação. Apresenta-se como o discernimento, furqān, entre a verdade, al-Haqq, (CORÃO 2: 144.147; 3, 6o) ${ }^{6}$ e o erro, al-bātil (SCHUON, 1989, p. 51):

\footnotetext{
${ }^{4}$ No verbete islamismo do Dicionário de espiritualidade, de Maurice Bormanns (1991), o termo que aparece como "consagração", na tradução de Samir El Hayek vem traduzido como "dar-se por inteiro".

${ }^{5}$ Hadițs (no singular Hadit e no plural ahadiț. Neste artigo, o plural foi "aportuguesado") são os ditos do Profeta que foram conservados por seus companheiros. É chamada de ciência, pois a elaboração das coleções de Hadițs demandou um grande trabalho de pesquisas e entrevistas. Com isto, a base destes Hadițs, que Ihes confere autoridade e veracidade, é a ciência do Isnad, isto é, a intrincada cadeia de testemunhos acerca da veracidade do que se diz e que remonta, normalmente, até os companheiros mais próximos do Profeta e que o ouviram dizer tal coisa. Nesta ciência ainda são incluídos os Hadits qudsi, isto é, ditos que retratam o que Deus disse. Pode-se resumi-los na seguinte formulação: "Muhammad disse que Deus diz".

${ }^{6}$ É interessante observar que a expressão al-Ḥaqq, 'a Verdade', é um dos nomes de Deus no Corão.
} 
Eis o livro que é indubitavelmente o guia dos tementes a Deus; que creem no incognoscível, observam a oração e praticam a caridade com o que lhes agraciamos; que creem no que te foi revelado (ó Muhammad), no que foi revelado antes de ti e estão seguros da vida futura. Estes possuem a orientação de seu Senhor e serão os bem-aventurados. (CORÃO 2: 2-6).

Por isso, o Corão está fortemente presente na vida muçulmana, em suas orações e atividades civis. Nele, os muçulmanos devem meditar e recitar continuamente com o intuito de "coranizar" suas vidas e adquirir a ciência da istinbāt, ou seja, a elucidação imediata do sentido de cada versículo. Para cumprir esta tarefa, devem seguir uma antiga regra Hambalita: "Não vá procurar duas passagens separadas do Corão para as confrontar; leia o Corão do começo ao fim". 7

Sua prosa, descontínua e entrecortada, permite uma maior invenção, livre das rimas poéticas. É sua primeira propriedade, segundo Louis Massignon (MASSIGNON, 1999b, p. 28). Sua segunda propriedade, ainda segundo Massignon, é seu caráter de "insinuada advertência" para fazer pensar sobre uma intenção primordial que se esconde no texto, mas que está para além dele, revelando a voz de um mensageiro.

Segundo Al-Ġazāli (+ 1111 do calendário cristão), "é recitado com a língua, escrito em volumes, guardado nos corações. Apesar disto, é eterno, subsistente na essência de Deus excelso, não sujeito a divisão nem separação por transferi-lo aos corações ou ao papel” (BORRMANS, 1993, p. 599). É o mais belo dos livros (CORÃO 17:88), ditado por Deus, não inspirado. Por isso deve ser meditado e saboreado pelo crente visando que se passe do seu sentido aparente (zāhir) ao seu sentido escondido (bātin).

${ }^{7}$ Malati, f. 373. Cf GOLDZIHER apud MASSIGNON, 1999a, p. 46. 


\subsection{Critérios de leitura do Corão: a língua árabe}

Para se aproximar de uma compreensão melhor do Corão, deve-se ter acesso aos aspectos especiais da gramática da língua árabe. Ela marca o estilo do pensamento corânico profundamente, sendo considerada pelos muçulmanos uma língua sagrada, ${ }^{8}$ legítima forma de manifestação da Palavra de Deus.

Toda língua registra a forma de pensamento de um povo, ao mesmo tempo em que é construída a partir da interação deste povo com a realidade e a história que o cerca. Neste sentido, a língua árabe também assinala uma concepção de mundo, de vida e de história.

Roger Arnaldez (MASSIGNON, 1999a) afirma que o árabe quase não emprega a subordinação. Isto é, ele se utiliza mais de preposições que de conjunções subordinativas, o que lhe faz alinhar os fatos sem enfatizar as relações lógicas que articulam o pensamento humano. Isto se relaciona com sua concepção de Deus, que ensina não por meio de raciocínios ou silogismos, mas por meio de uma relação direta e imediata com os seres humanos através de Sua Palavra.

Louis Massignon (1999b), por sua vez, mostra que não há, no árabe, tantos tempos verbais quanto nas línguas indo-europeias. A quantidade de tempos verbais indica um texto centrado no sujeito e nos seus atos, enquanto os verbos semíticos são mais convenientes à ação de Deus que habita na atemporalidade. Portanto, segundo Massignon, o árabe é uma língua teocêntrica, pois afirma a transcendência e a imanência do Agente único. Além disso, é uma língua que condensa as ideias, buscando o essencial e refletindo a dureza da vida em seu

\footnotetext{
${ }^{8}$ Segundo Fritjof Schuon, “é sagrado aquilo que, primeiro, se prende com a ordem transcendente, segundo, possui um carácter de absoluta certeza e, terceiro, escapa à compreensão e ao controle do espírito humano corrente. [...] O sagrado é a presença do centro na periferia, do imutável no movimento. [...] O sagrado introduz nas relatividades uma qualidade de absoluto, confere às coisas perecíveis uma textura de eternidade". (SCHUON, 1989, p. 56-57).
} 
ambiente histórico. 9

Johannes Lohmann (1999), ${ }^{10}$ de sua parte, em continuidade com a linha de raciocínio que entende que a língua traduz uma forma de pensar o mundo, faz um contraponto entre a língua árabe e a grega, no qual busca retratar as peculiaridades férteis de cada cosmovisão linguística. A língua/forma de pensamento árabe, designada por ma’na, não procura, como a grega, baseada no logos, fazer uma correspondência biunívoca entre a realidade e o pensamento. No universo grego, esta correspondência é efetuada através do verbo ser, presente na realidade e nos juízos. Ele "homo-loga o real” (HANANIA, 1999, p. 27), como se pode ver na filosofia de Parmênides que afirma que "Na verdade, pensar e ser é, ao mesmo tempo, a mesma coisa." (HANANIA, 1999, p. 27). O árabe é diferente, pois sua intenção não é acompanhar pari passu o ente, mas sim o sentido mental independentemente da correspondência entre o logos e a realidade. Daí decorre que sua ciência não seja a geometria (ciência grega por excelência), mas a álgebra, números negativos e irracionais, permitindo através da matemática, pensar a incomensurabilidade.

Além disso, a língua árabe estrutura-se não em radicais fixos, mas em radicais que se intraflexionam: SaLaM, iSLaM, SaLiM, muSLiM, etc. Eles são a alma da palavra árabe, sendo que as vogais têm um papel de articulação periférica. Destes radicais triconsonantais utilizados no exemplo acima se produzem vários significados: integridade física e moral, saúde, normalidade, salvação (em sentido religioso), submissão (de boa ou má vontade), acolhimento, conclusão de um assunto, paz.

E, de uma maneira complexa, além da possibilidade de uma articulação entre consoantes e vogais a partir de um mesmo radical, há também a possibilidade de metátese, isto é, de mudança na ordem das três consoantes, o que

\footnotetext{
9 "Por sí misma, la lengua árabe coagula y condensa, con un endurecimiento metálico, y por veces con una refulgencia cristalina, la idea que se quiere expresar, sin ceder a la presión del sujeto hablante. Elíptica y gnómica, discontinua y entrecortada... Ya la escritura árabe nos resalta esta densidad: de las palabras, sólo señala el cuerpo, las consonantes, las únicas escritas en negro sobre la línea; mientras que el alma de las palabras, su vocalización y entonación, no se anota sino facultativamente (y antaño en rojo) fuera de la línea". (MASSIGNON, 1999b, p. 23).

${ }^{10}$ Cf. tb. HANANIA, 1999.
} 
faz surgir um novo radical, que frequentemente tem uma conexão de sentido com o radical original. ${ }^{11}$

A esta criatividade na maneira de lidar com a língua e seus signos pode corresponder à liberdade e à criatividade no plano da existência e da vivência religiosa. Por isto Aida Ramezá Hanania (1999, p. 29) vai afirmar que

A liberdade existente no plano conceitual corresponde àquela existente no formal. A ausência do verbo ser no presente (quebrada apenas onde é necessária a ênfase, a insistência) atesta amplamente a tendência da língua a convocar a sensibilidade e a intuição. [...] Estes fatos da linguagem, aparentemente inocentes, trazem consigo profundos condicionamentos de visão de mundo e de mentalidade.

São justamente estes profundos condicionamentos de visão de mundo e mentalidade que apontam para singularidades na maneira de se aproximar da realidade e da experiência religiosa. Neste sentido, segundo Johannes Lohmann, o direcionamento que a língua árabe propicia ao muçulmano em geral é no sentido de trabalhar o sentido da escuta, pois se para os gregos o mundo está para ser "visto", para os árabes ele está para ser “ouvido" (LOHMANN, 1976, p. 32), percebido por ayat, conceito que se articula ao redor do termo signo e que pode ter vários significados, como "lei, manifestação, indicação e, principalmente, sinal de Deus”. O próprio Corão, com seus versos, é um ayat, que ensina a ler os āyat que o mundo e o ser humano são. Na verdade, tudo é um grande mațal, isto é, uma parábola, provérbio, que contém os vários āyat de Deus.

O Corão, portanto, é habitado, para o crente, por uma dimensão de Poder Sagrado enorme, que é intensificada pela qualidade de mistério que o ronda. $\mathrm{Na} 2^{\mathrm{a}}$ sura, em seu início, aparecem as letras árabes Alef, Lam, Mim. Elas apontam o mistério do Corão Sagrado, formado com letras do alifato árabe que indicam e

\footnotetext{
${ }^{11}$ São exemplos de metátese citados no livro de HANANIA, 1999, p. 29: SFR (viajar)/FRS (cavalo); KBR (fazer crescer)/BRK (abençoar)/BKR (primogênito); XRB (beber, brindar)/BXR (alegrar-se, anunciar boa nova); BHR (mar)/ RHB (amplo, espaçoso, ser bemvindo); TFL (criança pequena)/LTF (delicado, gracioso).
} 
enfatizam a impossibilidade, a incapacidade humana em produzir algo semelhante 12 e em compreendê-lo sem auxílio divino. ${ }^{13}$

\subsection{Critérios de leitura do Corão: a concepção de Livro Sagrado e Revelação}

Este caráter misterioso do Corão também vem reforçado a partir da concepção islâmica de revelação. A raiz árabe da palavra revelação (N-Z-L) é a mesma da palavra descer. Esta semelhança sinaliza que a revelação, do ponto de vista muçulmano, é como um descer do Altíssimo (tanzīl) ${ }^{14}$ ao nosso mundo: "É, em verdade, a Revelação do Senhor do Universo. O Espírito [Gabriel] digno de confiança o baixou (tanzīl) em seu coração, para que seja aquele que adverte" (CORÃO 26:192-194). Por isso a concepção de revelação para o Islã e para grande parte do mundo islâmico se concentra na tradição de uma transmissão literal, palavra a palavra, do Corão eterno por meio do anjo Gabriel ao profeta Muḥammad. ${ }^{15}$ Assim, o receptor desta revelação teve uma postura passiva, não interferente na manifestação de Deus, sem nenhuma iniciativa interpretativa, mesmo que esta revelação divina apareça exclusivamente por meio de sua voz (GINILKA, 2005, p. 58). Ao afirmar isto, não se está querendo dizer que o Corão é lido no meio muçulmano de forma literalista e que não haja interpretação. Mesmo porque, o Corão "é um texto árabe em muitas camadas. Mesmo aqueles que o ouvem o compreendem de diversas maneiras, por vezes divergentes” (LAWRENCE, 2008, p. 13) e, lido em um contexto histórico, ele "se torna Um Livro de Sinais, com múltiplas camadas em seus significados, continuamente

\footnotetext{
${ }^{12}$ Cf. a nota de Samir El Hayek, na versão portuguesa do Alcorão Sagrado (1980), p.4. Fritjof Schuon também aborda esta questão a partir da incoerência que algumas passagens do Corão parecem ter. Segundo ele, "A aparente incoerência de tais textos [...] tem sempre a mesma causa, ou seja, a incomensurável desproporção entre o Espírito, por um lado, e os limitados recursos da linguagem humana, por outro. É como se a pobre e coagulada linguagem dos mortais, sob a formidável pressão da Palavra celeste, se despedaçasse em mil pedaços ou como se Deus, para exprimir mil verdades, apenas dispusesse de uma dezena de palavras, facto que o obrigaria assim a alusões pesadas de sentido, a elipses, a condensações, a sínteses simbólicas". (SCHUON, 1989, .p. 53).

${ }^{13}$ "O Corão é como uma jovem recém-casada: mesmo que tentes tirar-lhe o véu, ela não se desvendará perante ti. Se te pões a discutir o Corão, nada descobrirás, alegria alguma chegarás assim a alcançar. E o Corão recusa dar-se a ti porque tentaste retirar-lhe o seu véu. Ao recorrer à astúcia, tornando-se feio e indesejável a teus olhos, é como se te dissesse: 'Eu não sou aquele que amas'. Ele pode, pois, revelar-se sob as mais diversas aparências". (RUMI, 1993, p. 302-305).

${ }^{14}$ É um descer do Senhor dos mundos (Corão 69: 38-43). Esta analogia com a descida quer indicar a transcendência divina a qual ninguém tem acesso. Ele se revela sem nenhum intermediário. Somente sua palavra desvela um pouco o seu ser. (PLATTI, 2000, p. 5152).

${ }^{15}$ Cf. CASPAR, 1983a, p. 84; CASPAR, 1983b, p. 73; CHARFI, 1983, p. 8 e GEFFRÉ, 1983, p. 22-24.
} 
reinterpretado por sucessivas gerações e diversas audiências” (LAWRENCE, 2008, p. 20).

Neste tópico, há uma grande distinção entre a concepção de revelação consignada em um texto sagrado presente na tradição judaico-cristã e na tradição muçulmana. Na tradição judaico-cristã, em seus Livros Sagrados, a revelação ocorre em um processo progressivo e histórico e vai ser registrada em um livro, a Bíblia, cujo processo redacional foi realizado durante um longo período de tempo, em que se compreende que os "autores sagrados" são inspirados por Deus para interpretar sua ação no mundo. Nesta concepção, entende-se que é Deus mesmo o autor das escrituras juntamente com os seres humanos situados em uma cultura e história, pois “escolheu homens dos quais serviu fazendo-os usar suas próprias faculdades e capacidades, a fim de que agindo Ele próprio neles e por eles, escrevessem, como verdadeiros autores, tudo e só aquilo que Ele próprio quisesse” $(\mathrm{DV}, \mathrm{n} .11)^{16}$

Neste sentido, pode-se entender que a Bíblia, forjada em grande parte como narrativa oral durante longo período de tempo, constitui-se a partir do colocar por escrito, em um momento posterior, a experiência do encontro com Deus que se manifesta e se revela na vida. Porém, no mesmo ato da transmissão oral e da redação, revelação na vida, inspiração e reflexão humanas se misturam, tornandose tudo isso Palavra de Deus.

Embora Joachim Gnilka (2005, p. 63) elabore sua reflexão em outro sentido, na direção de fazer uma separação entre os dois momentos ${ }^{17}$ do que veio a se constituir como livro sagrado - o momento da auto revelação divina na história e o momento do testemunho dessa auto revelação no marca da comunidade crente -, ele também indica que o forte da revelação judaico-cristã nasce de uma manifestação divina na realidade. Diz ele que

\footnotetext{
${ }^{16}$ IGREJA CATÓLICA. VATICANO II, 1962-1965. Constituição Dogmática Dei Verbum - DV.

${ }^{17}$ Poderia ser incluído aqui um terceiro momento, que é o da recepção do leitor da Palavra de Deus. Diz José Tolentino Mendonça (2015, p. 39): "O leitor é requerido, suposto e esperado pelo próprio texto".
} 
Os escritos do Antigo e do Novo Testamento abrem o acesso à revelação divina no sentido de que dão testemunho dela no marco da comunidade crente. Porém, em si mesmos não são a revelação. São o testemunho mais antigo e inspirado da auto revelação de Deus, isto é, da palavra de Deus dirigida ao povo de Deus e de sua atuação histórica para a salvação e a libertação dos homens, que alcançou em Jesus Cristo seu ponto culminante.

No caso do Judaísmo, a revelação ocorre na ação de Deus e através da eleição/aliança que Javé faz com Abraão, seus descendentes e, mais tarde, com o povo de Israel. Portanto, é uma revelação que acontece de maneira especial na história de um povo específico.

No caso do cristianismo, a revelação, iniciada na trajetória do povo hebreu, é, sobretudo, em sua forma mais plena, a pessoa de Jesus Cristo, embora sua mensagem tenha sido transmitida pela tradição dos Apóstolos, que a releram e a interpretaram à luz do evento pascal e se compreenderam como estando sob a inspiração do Espírito Santo.

Desta maneira, os Livros Sagrados judaico-cristãos, como a Torah, Tanach ou os Evangelhos e as cartas dos apóstolos, são escritos posteriormente aos eventos relatados, resultado de uma longa elaboração que envolveu a participação de muitos grupos que, muitas vezes, se situavam em épocas diferentes e partilhavam de concepções de fé, religião e teologia diversas. Portanto, a concepção de revelação presente no texto sagrado se encaixa em uma tradição histórico-interpretativa, na medida em que através da mediação humana inspirada pelo Espírito de Deus se interpreta a ação divina na história e no mundo. ${ }^{18}$

No caso do Corão, a revelação é a sua mensagem e o Profeta é apenas seu transmissor. Ela é concebida como uma Escritura pré-existente, ditada por Deus a Muhammad que deve transmiti-la fielmente, sem que sua subjetividade,

\footnotetext{
${ }^{18}$ DV - Constituição Dogmática Dei Verbum, 1986, capítulos II e III. Cf. tb. A interpretação da Bíblia na Igreja. “Esta recomendação (o estudo dos gêneros literários) parte da solicitude de compreender o sentido dos textos com toda a exatidão e precisão possíveis e, portanto, no seu contexto cultural histórico. Uma ideia falsa de Deus e da Encarnação leva certo número de cristãos a tomar uma orientação oposta. Eles têm a tendência a crer que, sendo Deus o Ser absoluto, cada uma das suas palavras tem um valor absoluto, independente de todos os condicionamentos da linguagem humana". JOÃO PAULO II, 1986, na apresentação do documento, p. 14.
} 
personalidade e o contexto histórico/social/cultural interfiram na mesma. É uma tradição de transmissão literal. Daí a tradição do nabi al ummi (CORÃO 7: 157158), isto é, o Profeta iletrado. ${ }^{19}$

Estas duas concepções diferentes de revelação, a histórico-interpretativa e a da transmissão literal, interferem na forma como cada uma destas religiões interpreta a ação de Deus, seus Livros Sagrados e os personagens destes livros. Um exemplo claro disto diz respeito à forma como os personagens bíblicos e os corânicos, que muitas vezes são os mesmos, são descritos ou apresentados. Na Bíblia, devido ao caráter específico de sua concepção de revelação, eles estão historicizados, e, portanto, carregam toda a diversidade decorrente de sua interação com seu contexto vital. No Corão, eles aparecem sempre em relação com o Eterno, com Allāh, e não fazem mais que repetir e chamar a atenção para uma mesma e única mensagem: não há Deus além de Deus. Não se nega a historicidade destes personagens, mas a importância do que eles dizem é dada pela capacidade de manifestar a essência divina: “A recordação corânica só retém os tempos fortes, descontínuos, da vida dos personagens da Torah: os momentos onde eles estão em relação vertical com Deus, momentos portadores de revelação” (ARNALDEZ, 1988, p. 85).

No entanto, mesmo o Corão ocupando este lugar de destaque dentro da tradição islâmica, ele não se confunde nem com Allāh e nem com a "Mãe da Escritura” ou "Livro Matriz" (Corão 13: 39), isto é, o modelo arquetípico eterno e imutável de onde veio a revelação. Assim sendo, a "Mãe da Escritura" é mais ampla que o Corão, que, somente revela partes dela, devido à sua incomensurabilidade. Quanto à Torah e ao Evangelho, estão incluídos na "Mãe da Escritura”, mas não é a mesma Torah dos Judeus ou Evangelho dos Cristãos, pois, segundo a concepção islâmica, estas escrituras foram falsificadas (tabrīf). Daí a compreensão islâmica

\footnotetext{
${ }^{19}$ Apesar dessa concepção assumida pela maioria dos muçulmanos, hoje já existem grupos de teólogos islâmicos que pensam a possibilidade de uma hermenêutica do Corão, principalmente fundamentando-se teologicamente na concepção da Mãe da Escritura ("Fizemos um Corão árabe para que o possais compreender. O original, conservado junto a nós, é sublime, cheio de sabedoria". Corão 43:3-4), que é maior que o Corão escrito (Mušaf) e que é captada parcialmente através da recitação, que é sua emanação. (GEFFRÉ, 1992, p. 13-14).
} 
quanto à necessidade da revelação corânica, que, além de verdadeira, sem deturpação humana, vem complementar o que faltava às demais.

\section{Allāh}

A grande manifestação corânica surge como manifestação da palavra incriada de Allāh. Da mesma forma, é Ele quem tira o universo do caos (CORÃO 21: 30), fazendo-o perfeito e harmônico (CORÃO 67: 3-4), num ato de contínuo criar (CORÃO 55: 29). Ele se manifesta nas coisas insignificantes (CORÃO 2: 26, onde até o mosquito é seu sinal), assim como na grandiosidade da natureza:

Na criação dos céus e da terra, na alternação do dia e da noite; nos navios que singram o mar para o benefício do homem; na água que Deus envia do céu, com a qual vivifica a terra, depois de haver sido árida e onde disseminou toda a espécie animal; na mudança dos ventos; nas nuvens situadas entre o céu e a terra, nisso tudo há maravilhas (mensagens, sinais, ayāt) ${ }^{20}$ para os sensatos. ${ }^{21}$

Allāh é o absolutamente transcendente, o "Totalmente Outro", que está além da compreensão de qualquer pessoa. É invisível para o ser humano, $\dot{g} a y b$ (CORÃO 2: 33; 16: 77; 49: 18), embora esteja mais próximo dele que sua própria veia jugular. ${ }^{22}$ Transcendência, portanto, não significa distanciamento, pois Deus é $q u r b$, proximidade, isto é, é um Deus compassivo, que se aproxima do ser humano com intimidade e lhe revela seus desígnios, uma vez que não há possibilidade de acesso à sua intimidade.

\footnotetext{
${ }^{20}$ Àyat/ayāt aparecem 372 vezes no Corão como sinal de Deus. Cabe ao ser humano ler e interpretar estes sinais. A natureza também é um livro de Deus. O Corão é o código que possibilita o decifrar destes sinais no mundo natural.

${ }^{21}$ CORÃO 2: 164; cf. também CORÃO 3:190; 10:5; 16:69; 50:37.

${ }^{22}$ Embora seja um Deus presente (CORÃO 50: 16 - "mais perto dele do que sua artéria jugular"), está acima de todo conhecimento (Corão 6: 59). Segundo um hadiț: "Deus tem setenta véus de luz e trevas. Se ele os afastasse, o sublime resplendor de sua face queimaria tudo o que dele se aproximasse com seu olhar". (BORRMANS. 1991, p. 603). Ele é o Todo Poderoso (citado desta maneira em 142 versos do Corão) embora seja o Misericordioso e o Clemente (afirmação que está na abertura de quase todas as suras do Corão), o que age com Misericórdia (citado em 194 versos do Corão, repartidos em 72 suras).
} 
Esta transcendência se manifesta no fato de que Ele é diferente de tudo o que se conhece, nada se lhe pode comparar (CORÃO 42: 11; 112). Concretamente, ela se faz presente na recusa à toda intermediação e intermediário entre Allāh e o ser humano, com exceção do Corão. No Islã não há igreja, sacramentos, sacerdócio. Também não há magistério: segundo o reitor da universidade Al-Ażar, do Cairo, em um manual clássico, “os decretos dos ‘jurisconsultos’ (fuqaha) oficiais somente têm o valor de conselho para cada muçulmano, que deve decidir segundo sua consciência” (SHALTUD, 1964, p. 567-571).23 Mesmo suas liturgias, realizadas em mesquitas sóbrias, são significativas: o crente está só diante de Deus, inclusive nos momentos de oração comunitária.

No Corão são citados 99 nomes de Deus, que representam os qualificativos da realidade divina: o Benfeitor, o Misericordioso, o Clemente, o Onipotente, o Vivente, o Subsistente, o Santo, o Criador, o Dador de todo bem, o que perdoa, o Justo, o Bom, o Sábio, o Único, o Amável, o Dominador, o Vitorioso, o Vingador. O centésimo nome, al ism, que quer dizer "nome máximo", é um segredo que pertence somente a Allāh. É um nome impronunciável e conhecido somente pelos místicos mais iluminados.

Embora estes nomes indiquem uma multiplicidade, na verdade há um só Deus. ${ }^{24}$ Ele é único em relação a não existência de outra divindade e em relação a não haver multiplicidade em seu seio. Esta multiplicidade de nomes divinos surge devido à limitação da linguagem humana, que não tem como abarcar a realidade infinita de Allāh.

\footnotetext{
${ }^{23}$ Cf. tb. CASPAR, 1983a, p. 82.

${ }^{24}$ Se no início da revelação corânica se pode encontrar traços de henoteísmo através do grito de guerra muçulmano 'Allāh Akbar' (Deus é maior), logo em seguida se nega a possibilidade da existência de qualquer outra divindade. Na verdade, a questão da existência de Deus nunca foi um problema para o Corão, pois ela não era questionada. "Quando muito, pode-se assinalar a polêmica alcorânica contra a crença num destino impessoal que regularia a vida e a morte, a riqueza e a pobreza, e que permitiria aos ricos desinteressarem-se da sorte dos pobres. O Alcorão afirma com vigor que só Deus faz viver e morrer e que o rico será julgado e condenado pela sua atitude (Alcorão 36: 47; 45: 24)". (CASPAR, 1991, p. 75; cf. tb. CASPAR, 1985, p. 73).
} 
Deus é único, 25 sem qualquer associado à Sua divindade, o que seria denominado de širk, isto é, o pecado por excelência que faz associação de outro ser a Deus ou se faz de Deus uma imagem idolátrica. ${ }^{26} \mathrm{O}$ crente muçulmano é convocado a fazer a Tawhīd, isto é, a profissão da unicidade divina. Por isso, ele é chamado de muwahhid, isto é, aquele que afirma a unicidade de Deus, tanto externamente como internamente. A sura $112^{27}$, a sura do Tawḥ̂̀d, afirma esta unicidade de Deus e o denomina a partir de um termo difícil de traduzir: samad, isto é, Ele é o Único, a Plenitude, o Impenetrável, o Indissociável. É uma unicidade misteriosa $^{28}$ que quer a justiça (Corão 90: 12-17; 55: 7-9) e a verdadeira virtude (CORÃO 2: 177), sendo seus desígnios inexoráveis (CORÃO 16: 1).

Ele também é "suficiente procurador" (CORÃO 4: 81) do ser humano, Aquele que "nos basta, que é bom procurador" (CORÃO 3: 173) e é mu'mim, 29 isto é, Aquele que “põe em segurança”. A Ele o muçulmano deve abandonar-se totalmente e defender a fé em sua unicidade, que não se trata apenas de uma “atitude do coração", mas, antes, um testemunho que se manifesta na sua relação com o mundo, com a sociedade e seus ídolos, antigos e modernos.

A crença em Deus como ser transcendente e único traz algumas consequências para o Islã. No plano do conhecimento, ela afeta a fé e a teologia muçulmanas. No Corão, não há separação entre fé e obras, sendo que as exigências de solidariedade fazem parte da vivência da fé. Há, portanto, uma unidade entre fé, teologia e obras.

\footnotetext{
${ }^{25}$ O Papa João Paulo II, dirigindo-se aos jovens marroquinos em Casablanca, no dia 19 de agosto de 1985, afirmou: “Cremos no mesmo Deus, o Deus único, o Deus vivo, o Deus que cria os mundos e leva os mundos à sua perfeição". Embora se possa afirmar que cristãos, muçulmanos e judeus creem em um mesmo Deus, a forma de conceber sua unicidade é diferente. No Judaísmo o monoteísmo é soteriológico e surge no âmbito da Aliança entre Deus e o povo escolhido. No Cristianismo, este monoteísmo é mediado por Jesus Cristo e assumido no seio de uma diferenciação intra-trinitária. No Islã, por sua vez, o monoteísmo é ontológico e dogmático, sem ligação direta com uma aliança histórica. A unicidade de Deus está inscrita na natureza original da criação e do ser humano, pois, segundo o Corão 7, 172-173, na pré-eternidade já se realizou uma profissão de fé nesta unicidade. Por isto, segundo um hadit de Muhammad, "Todo recém-nascido é muçulmano; seus pais é que o fazem judeu, cristão, masdeíta". (GEFFRÉ, 2001, p. 92).

${ }^{26}$ Segundo o reformista Mohammed 'Abduh, morto em 1905, a passividade que espera tudo de Deus e abdica de toda responsabilidade humana frente ao mundo também pode ser considerada um širk, pois não é este o Deus que o Corão revela.

${ }^{27}$ Esta sura, juntamente com a primeira, a Fātiha, é uma das mais conhecidas do mundo islâmico, aparecendo muitas vezes em letras cúficas nos mihrab das mesquitas, em quadros nas casas, nas moedas, etc.

${ }^{28} \mathrm{Cf}$. CORÃO 2, 255; 10,39; 20, 110; $27: 84$.

${ }^{29}$ Cf. CORÃO 59, 23. Cf. tb. CORÃO 11, 88: "Meu êxito não depende senão de Deus; nele confiei, a ele recorro cheio de esperança".
} 
Por sua vez, a fé é compreendida como um dom de Deus infundido no coração do crente ${ }^{30}$ e "se caracteriza por ser de tipo sobrenatural" (CASPAR, 1985, p. 75), pois crê no Deus único porque Ele disse que é único. Além disso, nada se pode dizer de Deus em linguagem humana, pois nada é semelhante a Ele. Assim, em seu íntimo Ele não pode se revelar em sua totalidade, pois a revelação é feita em linguagem humana e dirigida aos seres humanos (CASPAR, 1985, p. 75).

No plano da ação de Deus sobre o ser humano e o mundo, também a tendência é a afirmação de Deus como o único existente e, consequentemente, o único agente. O ser humano é o lugar da ação de Deus nele, segundo uma tradução do Corão: "Ele vos criou, vós e os vossos atos". (CORÃO 37: 96).31

No plano social, a unicidade de Deus leva a rejeitar a separação entre o temporal e o espiritual, entre vida civil e vida religiosa. A šari’a, isto é, a "via direta”, reflete esta cosmovisão. Ela é composta pela 'ibadat, ou seja, por normas que regulamentam os atos de culto, e também pela mu'amalat, ou seja, por normas que regulamentam as relações da sociedade. Entre estas duas dimensões há um caráter de unidade. Segui-las é seguir a vontade de Deus que se faz presente tanto no culto quanto na organização da sociedade. A šari’a traduz a máxima: "só Deus possui, só Deus manda, só Deus sabe” (GARAUDY, 1993, p. 125).32

Além disso, em termos religiosos, a espiritualidade islâmica não separa o mundo da piedade interior e o mundo dos rituais exteriores, pois

\footnotetext{
30 "A estes Deus Ihes cunhou a fé nos corações...". CORÃO 58, 22.

${ }^{31}$ Deve-se observar que esta tese afirmada neste parágrafo (tese do atomismo ou ocasionalismo muçulmano) foi recusada por algumas escolas teológicas islâmicas. "Para os mu'tazilistas, o homem é de fato 'criador' de seu ato e até criador único; para os grandes aš'aritas, como Gazâli, Deus e o homem são ambos causas do ato humano: Deus como criador universal e o homem como 'aquiescente' de seu ato. Para os reformistas como M. 'Abduh (m. em 1905) o homem faz seu ato e Deus, se for necessário, o 'completa'. E o islã moderno é em peso voluntarista, para não dizer 'horizontalista'." (CASPAR, 1985, p. 76).

${ }^{32}$ Garaudy, neste livro, faz uma distinção interessante entre a šari'a, lei divina eterna, e a fiq, a legislação que procura concretizar a šari'a no contexto histórico. Para ele, seria um erro confundir estas duas dimensões da legislação, pois seria tornar eterno o que é fruto de um momento histórico particular.
} 
Tudo possui um aspecto externo (al-zāhir) e um interno (al-bātin), ou seja, um aspecto que se manifesta exteriormente e outro que conecta cada coisa internamente ao mundo espiritual. Ao mesmo tempo, o espiritual não é simplesmente equivalente ao esotérico, enquanto esse se opõe ao exotérico. Embora o espiritual esteja mais proximamente relacionado à dimensão esotérica (al-bātin) do Islã do que a qualquer outro aspecto da religião, relaciona-se também com os atos exotéricos, com a Lei Divina, com a teologia, a filosofia, as artes e as ciências criadas pelo Islã e sua civilização. O exotérico, entretanto, sempre sinaliza a possibilidade de uma jornada na direção da interioridade (SCHWARTZ, 2001, p. 15).

Esta ideia da Unidade que perpassa toda a espiritualidade islâmica também pode ser formulada de outra maneira, utilizando-se, para isto, de outro par de termos: tanzil e ta'wil. O primeiro faz referência à religião enquanto manifestação observável objetivamente que desce do trono de Allāh. É a letra da revelação, seus rituais, suas leis. Já o termo ta'wil pode ser compreendido a partir do conceito de ascensão, de retorno à origem, à raiz. Portanto, é de um caráter mais gnóstico e esotérico, que se realiza na interioridade. Assim como o exotérico, o tanzil deve sinalizar uma jornada rumo ao ta'wil.

\section{Conclusão}

Após este percorrido, se pode ter uma ideia ampla da espiritualidade islâmica em seus fundamentos. Alguns elementos importantes, como o papel do Profeta Muhammad assim como o papel dos cinco pilares não foram abordados neste momento. Ficam para um próximo artigo. Entretanto, sua base corânica e sua concepção particular de Deus e de revelação já nos dão os limites e as bordas por onde passa a vivência espiritual dos muçulmanos. E esta vivência, em absoluto, se restringe ou é caracterizada por expressões menores - em termos numéricos e qualitativos - representadas pelos islamitas. 33

\footnotetext{
${ }^{33}$ Por Islamitas aqui se faz referência aos grupos fundamentalistas e radicais existentes no Islã.
} 
Caracteriza-se, portanto, a experiência islâmica como uma vivência rica e singular na história das religiões, vindo a somar no largo espectro de experiências da humanidade frente à vida e ao Sagrado. Nela, Deus é o único existente. Tudo mais provará o perecimento. (CORÃO 55: 26-27). O muslim, o praticante do Islam, vive neste espírito, centrado em Deus, animado por um profundo sentimento de dependência da divindade, buscando a submissão a Deus, a entrega de si e a atitude de adoração contínua, tanto em suas práticas religiosas quanto em seu cotidiano, pois, para os muçulmanos, não há separação entre Sagrado e Profano. Tudo se reveste de sacralidade e tudo deve ser incluído na Unidade fundamental que nasce de Allāh que a tudo sustenta.

\section{REFERÊNCIAS}

ALCORÃO SAGRADO. Tradução de Samir el Hayek. Rio de Janeiro: Otto Pierre Editores, 1980.

ALI-SHAH, Sidar Ikbal. Lights of Asia. Londres: Tractus Books, 1998.

ARMSTRONG, Karen. Uma história de Deus. São Paulo: Companhia das Letras, 1998.

ARMSTRONG, Karen. Maomé: uma biografia do Profeta. São Paulo: Companhia das Letras, 2002.

ARNALDEZ, Roger. Figure patriarcales et prophétiques dans le coran. Lumiere et Vie, Lyon, v. 37, n. 188, p. 81-95, set. 1988.

ARNALDEZ, Roger. Avant-propos. In: MASSIGNON, Louis. Essai sur les origines du lexique technique de la mystique musulmane. Paris: Les Editions du Cerf, 1999. p. I - XXII.

ASHRAF, Syed Ali. O significado interior dos ritos islâmicos: prece, peregrinação, jejum e jihad. In: BARTHOLO JR., Roberto S.; CAMPOS, Arminda. Islã: o credo é a conduta. Rio de Janeiro: ISER/Imago, 1990.

BARTHOLO JR., Roberto. Mística e política no seguimento ao profeta do Islã. In: BINGEMER, Maria Clara; BARTHOLO JR., Roberto. Mística e política. São Paulo: Loyola, 1994. 
BAUSANI, Alesandro. L'islam. Milano: Garzanti, 1995.

BORRMANS, Maurice. Orientamenti per un dialogo tra cristiani e musulmani. Roma: Urbaniana University Press, 1991.

BORRMANS, Maurice. Islamismo. In: FIORES, Stefano de; GOFFI, Tullo. Dicionário de espiritualidade. São Paulo: Paulus, 1993.

BUCKHARDT, Titus. Introduzione alle Dottrine Esoteriche dell'Islam. Roma: Edizione Mediterranee, 1987.

CASPAR, Robert. Groupe de Recherches Islamo-Chrétien. Lumiere et Vie, Lyon, n. 163, p. 81-85, Jul/Ago 1983a.

CASPAR, Robert. La encontre des théologies. Lumiere et Vie, Lyon, n. 163, pp. 63-80, Jul/Ago 1983b.

CASPAR, Robert. O significado permanente do monoteísmo do islã. Concilium, Petrópolis, v. 197, 1985/1.

CASPAR, Robert. Cristianismo/Islamismo. Porto: Editorial Perpétuo Socorro, 1991.

CHARFI, Abdelmajid. La revelation du coran et son interpretation. Lumiere et Vie, Lyon, n. 163, p. 5-20, jul./ago. 1983.

CHEBEL, Malek. Les symboles de l'Islam. Paris: Editions Assouline, 1999.

DELUMEAU, Jean. As grandes religiões do mundo. Lisboa: Editorial Presença, 1997.

GARAUDY, Roger. El islam en occidente: Córdoba, capital del pensamiento unitario. Madri: Editorial Breogan, 1987.

GARAUDY, Roger. Promessas do Islã. Rio de Janeiro: Nova Fronteira, 1988.

GARAUDY, Roger. Deus é necessário?. Rio de Janeiro: Jorge Zahar Editores, 1993.

GARDET, Loius. Expériences mystiques em terres non-chrétiennes. Paris:

Editions Alsatia, 1953.

GEFFRÉ, Claude. Le coran, une parole de dieu différente? Lumiere et Vie, Lyon, n. 163, p. 21-32, jul./ago. 1983 .

GEFFRÉ, Claude. La portée théologique du dialogue islamo-chrétien. Islamochristiana, Roma, n.18, p. 1-23, 1992.

GEFFRÉ, Claude. O Deus uno do islã e o monoteísmo trinitário. Concilium, Petrópolis, v. 289, n. 1, p. 91-99, 2001. 
GNILKA, Joachim. Bíblia y corán. Lo que los une, lo que los separa. Barcelona: Herder Editorial, 2005.

HANANIA, Aida Ramezá. A caligrafia Árabe. São Paulo: Martins Fontes, 1999.

HIRJI, Zulfikar. Diversity and pluralism in Islam. Londres: Istitute of Ismaili Studies, 2010.

HOURANI, Albert. Uma história dos povos árabes. São Paulo: Companhia das Letras, 1994.

IGREJA CATÓLICA. VATICANO II. 1962-1965. Constituição Dogmática Dei Verbum. Petrópolis: Vozes, 1986.

JOMIER, Jacques. Islamismo: história e doutrina. Petrópolis: Vozes, 1993.

KONIG, F.; WALDENFESL, H. Léxico das religiões. Petrópolis: Vozes, 1998.

LAWRENCE, Bruce. O Corão. Uma biografia. Rio de Janeiro: Zahar, 2008.

LOHMANN, Johannes. Saint Thomas et les Árabes (Structures linguistiques et formes de pensée). Revue Philosophique de Louvain, Louvain, v.74, n. 21, p. 30-44, fev. 1976.

MASSIGNON, Louis. Essai sur les origines du lexique technique de la mystique musulmane. Paris: Les Editions du Cerf, 1999a.

MASSIGNON, Louis. Ciencia de la compasión: escritos sobre el Islam, el lenguaje místico y la fe Abrahámica. Madri: Trotta, 1999b.

MENDONÇA, José Tolentino. A leitura infinita. A Bíblia e a sua interpretação. São Paulo: Paulinas, 2015.

PLATTI, Emilio. Islam... Étrange? Au-delà des apparences, au coeur de l'acte d'islam, acte de foi. Paris: Editions du Cerf, 2000.

PONTIFÍCIA COMISSÃO BÍBLICA. A interpretação da Bíblia na Igreja. São Paulo: Paulinas, 1999.

TEIXEIRA, Faustino. A experiência de Deus nas religiões. Numen, Juíz de Fora, v. 3, n. 1, p. 111-148, jan./jun. 2000.

RUMI. Kitâb fihi mâ. Rio de Janeiro: Edições Dervish, 1993.

SHALTUT, M. Al-Islam, 'aqida wa-shari’a, 2. ed. Le Caire: [al-Qahirah?] [al-Maktab alFannì lil-Nashr], 1964.

SCHUON, Frithjof. Compreender o Islão. Lisboa: Publicações Dom Quixote, 1989. 
SCHUON, Frithjof. Islã. In: BARTHOLO JR., Roberto S.; CAMPOS, Arminda. Islã: o credo é a conduta. Rio de Janeiro: ISER/Imago, 1990.

SCHWARTZ, Sílvia. O suspiro do compassivo: uma contribuição de Ibn' Arabi para a perspectiva contemporânea do pluralismo religioso. 2001. 169 p. Dissertação (Mestrado) Universidade Federal de Juíz de Fora, Programa de Pós- Graduação em Ciências da Religião, Juíz de Fora.

SOUZA, Carlos Frederico Barbosa. No mais profundo centro: João da Cruz e os Sadilies cantam a união transformante. 2002. Dissertação de Mestrado - Universidade Federal de Juíz de Fora, Programa de Pós-Graduação em Ciências da Religião, Juíz de Fora.

SOUZA, Carlos Frederico Barbosa. A mística do coração: a senda cordial de Ibn 'Arabī e João da Cruz. São Paulo: Paulinas, 2010. 